\title{
Fattening Cattle Salt Supplementation and Watering Practices of Urban and Peri-Urban Cattle Fatteners in Dessie and Kombolcha Towns, Ethiopia
}

\author{
Kassahun Ahmed Seid (M.Sc) \\ College of Agriculture, Arba Minch University, P.O. Box 21 Arba Minch, \\ Ethiopia \\ Berhan Tamir (Professor, PhD), \\ Ashenafi Mengistu (Associate professor, PhD) \\ College of Veterinary Medicine and Agriculture, Addis Ababa University, \\ P.O. Box 34, Debre-Zeit, Ethiopia
}

URL:http://dx.doi.org/10.19044/esj.2017.v13n9p22

\begin{abstract}
The aim of this research was to investigate the cattle fattening system and its structure in urban and peri-urban kebeles of Dessie and Kombolcha towns, Ethiopia where scientific intervention could be initiated for further improvement in fattening practices. In this study structured questionnaire administered to a total of 337 cattle fattener households (190 from Dessie and 147 from Kombolcha towns). Complete enumeration techniques were applied to select urban and peri-urban kebeles. The entire cattle fatteners (100\%) in Dessie and Kombolcha towns were provide water for fattening cattle. Pipe and hand wells were the identified water sources in both study towns. $100 \%$ and $49.4 \%$ of peri-urban cattle fatteners in Dessie and Kombolcha towns were totally used hand wells, whereas, the entire urban fatteners $(100 \%)$ in both study towns and $50.6 \%$ peri-urban cattle fatteners in Kombolcha town were used pipe as water source for their fattening cattle. The entire cattle fatteners $(100 \%)$ in both study towns were provide water for fattening cattle by taking the water to the cattle. Majority of peri-urban $(71.8 \%, 66.7 \%)$ and the entire urban cattle fatteners $(100 \%, 100 \%)$ in Dessie and Kombolcha towns, respectively, were provided water in each day with no watering interval, respectively. $100 \%$ and $75.8 \%$ of urban cattle fatteners in Dessie and Kombolcha towns were provided water as a free choice or adl-bitum, whereas, $65.8 \%$ and $90.1 \%$ of peri-urban cattle fatteners were provided dominantly once per day, respectively. In the current both study towns all of urban and peri-urban cattle fatteners (100\%) were provide salt for fattening cattle. The entire peri-urban (100\%) and urban $(100 \%)$ cattle fatteners in both study towns were provided salt in the form of
\end{abstract}


block or locally called 'Ganfur' and via mix with the ration, respectively. Therefore, fattener's water and salt provision practices should be appreciated and supported with scientific knowledge.

Keywords: Fattening Cattle, Salt supplementation, Watering practices

\section{Introduction}

Diets are balanced for carbohydrate (energy), protein, vitamins, and minerals so cattle can achieve a desired level of performance, but cattle have a requirement for water too, and animal performance can be affected by water intake. In fact, of these nutrients, water is most critical. Anything influencing cattle physiology needs or losses will influence the water needs of livestock. Under conditions of restricted water intake, an animal may concentrate its urine by reabsorbing a greater amount of water than usual. While this capacity for urine concentration is limited, it can reduce the water requirement. When an animal consumes a diet high in protein or in salt or containing substances having a diuretic effect, the excretion of urine increases and there is an increased water requirement. If the environmental temperature and/or physical activity increases, water losses through evaporation and sweating increases (Aaron and Rick, 2011).

Beef cattle require a number of minerals for optimal growth and reproduction. Selecting the correct mineral supplement is important for maintaining healthy animals, and optimal growth and reproduction (Lawton, 2013). Moreover, one management tool frequently used is regulating feed intake with salt. Research suggests that regulating feed intake with salt is not precise; meaning that salt content may need to be adjusted throughout the feeding period to achieve the desired feed intake. Improvement in cattle productivity can be achieved through identification of water and watering practices and salt supplementation activities and introduction of new technologies or by refining existing practices in the system. Particularly, doing such research on small holder cattle fattening systems in urban and peri-urban areas, it is necessary to find out the existing salt supplementation and watering practices to develop a sustainable beef cattle production system. This is because, cattle fattening is an effective tool for poverty alleviation and has become an important business of the small farmers as well as urban dwellers. Particularly, the sector is good opportunity for employment and income generation for the rural poor, especially landless, destitute and divorced women (Aaron and Rick, 2011). Therefore, assessment of such practices is a prerequisite to bring improvement in cattle productivity in the low income countries. Hence, the present study was conducted to appraise watering and salt supplementation practices of cattle fatteners in urban and peri-urban kebeles of Dessie and Kombolcha towns of Ethiopia. 


\section{Materials and Methods \\ Description of the Study Area}

The study was conducted in Dessie and Kombolcha towns. Dessie is located in northern part of Ethiopia in Amhara National Regional State, South Wollo Zone at a distance of $400 \mathrm{~km}$ from Addis Ababa, Ethiopia. Its astronomical location is at $11^{\circ} 8^{\prime} \mathrm{N}-11^{\circ} 46^{\prime}$ North latitude and $39^{\circ} 38^{\prime} \mathrm{E}$ 41013' East longitude. Relatively it is bounded by KutaberWoreda in the north, Dessie Zuriya Woreda in the east, and by Kombolcha town in the south. The topography of Dessie is a highland type surrounded by 'Tossa' mountain (Dawit, 2013). Its elevation ranges between 2,470 and 2,550 meter above sea level (http://en.wikipedia.org/wiki/Dessie, retrieved in December 2014). Annual maximum and minimum temperatures of Dessie are $23.7{ }^{\circ} \mathrm{C}$ and $9{ }^{\circ} \mathrm{C}$, respectively, recorded in 2015 (Kombolcha meteorology station). Dessie is one of the reform towns in the region and has a city administration consisting of municipality, 10 urban and 6 peri-urban kebeles.

Kombolcha is an industrial town found in the north-central part of Ethiopia in South Wollo Zone of the Amhara Regional State of Ethiopia. It is situated at a distance of $377 \mathrm{~km}$ from north of Addis Ababa, $505 \mathrm{~km}$ from the Regional capital city, Bahirdar, $23 \mathrm{~km}$ from the zonal town Dessie and 533 $\mathrm{km}$ from port Djibouti. Astronomically, the town is located at about $11^{\circ} 6^{\prime} \mathrm{N}$ latitude and $39^{\circ} 45^{\prime} \mathrm{E}$ longitudes. The delimitation of the town is bounded by Dessie Zuria Woreda in the North East and North West, KaluWoreda in the South and Albuko Woreda in the South West (Muluwork, 2014). Mean annual rainfall is $1046 \mathrm{~mm}$ while annual maximum and minimum temperatures are $28.1{ }^{\circ} \mathrm{C}$ and $12.9{ }^{\circ} \mathrm{C}$, respectively, recorded in 2015 (Kombolcha meteorology station). The town is located in a range of altitudes between 1,500 and 1,840 meter above sea level. Kombolcha is one of the reform towns in the region and has a town administration municipality, 5 urban and 6 peri- urban kebeles (Eskinder, et al., 2010).

\section{Sampling Procedure and Sample Size}

Based on objectives of the research and the parameter required pre tested structured questionnaire was prepared. The questionnaire comprised data or information on water provision practices and water sources, watering frequency, watering gap/interval, provision mechanism and amount provided. Salt supplementation practices, mechanism of salt provision, frequency of salt provision and amount of salt provided. Consequently, those urban and peri-urban kebeles where a cattle fattening is practiced, were considered in both study towns. Accordingly, 3 and 6 urban, 4 and 6 periurban kebeles were selected from Dessie and Kombolcha towns, respectively. Complete enumeration technique was applied to select urban and peri-urban kebeles. Due to manageable number of cattle fatteners, 
complete enumeration technique was applied to select individuals from urban and peri-urban kebeles of Kombolcha town. While, systematic random sampling technique for peri-urban and complete enumeration technique for urban cattle fatteners was applied to select individual household in Dessie town. In peri- urban kebeles of Dessie town, sampled households were determined based on the principle of probability proportional to size'. The sample size (n) was determined using the formula recommended by (Arsham, 2007) $\mathrm{N}=0.25 / \mathrm{SE}^{2}$ Where: $\mathrm{N}$ : number of sample, SE: standard error, with the assumption of 4\% SE. Consequently, 190 (41 urban and 149 peri-urban) from Dessie and 147 (66 urban and 81 peri-urban) cattle fatteners household from Kombolcha town were selected and interviewed.

\section{Data Collection and Analysis}

A single visit formal survey was employed to collect all the required data. To strengthen the survey data, group discussions were held with individuals who have knowledge and experience on cattle fattening practices. In addition, key informant interviews were made with towns and kebeles Agricultural Experts, and Development Agents. Field observation was carried out to take different pictures. Researcher personal observation together with his practical experience in the study towns related to cattle fattening were also incorporated. Accordingly, focus group discussions and key informant interviews were conducted between February and April, 2016 whereas the household level surveys were carried out in May, June, July and August of the year 2016. Consequently, all the collected data were coded and entered into a data base using statistical package for social sciences (SPSS). Descriptive statistics such as mean, percentiles, and frequencies were used to analyze the data using the SPSS statistical software (SPSS for windows, release 20,2011 ).

\section{Results}

\section{Water provision practices and water sources}

The entire cattle fatteners $(100 \%)$ in Dessie and Kombolcha towns were provide water for fattening cattle. Pipe and hand wells were the identified water sources in both study towns. $100 \%$ and $49.4 \%$ of periurban cattle fatteners in Dessie and Kombolcha towns were totally used hand wells, whereas, the entire urban fatteners $(100 \%)$ in both study towns and $50.6 \%$ peri-urban cattle fatteners in Kombolcha town were used pipe as water source for their fattening cattle (Table 1). The data indicated that all of cattle fatteners in both study towns were used pure water for fattening purpose. This is due to better accessibility of water in both study towns. This result was similar with Tsegay et al. (2016) who indicated that farmers in Hadya Zone, watered their fattening cattle from river $(33.63 \%)$, tape water, 
$(25.45 \%)$, pond $(12.72 \%)$, rainfall $(10.9 \%)$ and well $(8.18 \%)$ sources in order of their importance. The three types of water sources identified in Harshin District are wells (73.3\%), ponds (20\%), and lakes (6.7\%) (Fikru, 2015). Provision of clean, fresh water is always a goal for the livestock producer. There are a number of items that affect water quality. Producers need to adopt management practices that do not negatively impact water quality (Aaron and Rick, 2011).

\section{Watering frequency, provision mechanism and amount provided}

The entire cattle fatteners $(100 \%)$ in both study towns were provide water for fattening cattle by taking the water to the cattle. Majority of periurban $(71.8 \%, 66.7 \%)$ and the entire urban cattle fatteners $(100 \%, 100 \%)$ in Dessie and Kombolcha towns, respectively, were provided water in each day with no watering interval, respectively. The rest were provided two and three days after. $100 \%$ and $75.8 \%$ of urban cattle fatteners in Dessie and Kombolcha towns were provided water as a free choice or adl-bitum, whereas, $65.8 \%$ and $90.1 \%$ of peri-urban cattle fatteners were provided dominantly once per day, respectively. The rest were provided twice per day (Table 1). Regarding watering frequency the current result indicates that water source, availability, water provision mechanism and knowledge regarding water intake has the limiting factor of water provision practices and watering frequency. This is because urban cattle fatteners were provide free choice with no interval, while, this practice was not true in case of periurban kebeles. Moreover, within peri-urban cattle fattener in both study towns the watering frequency was differs. According to Shitahun (2009) and Fikru (2015) report farmers offered drinking water for their fattening cattle once, twice and three times per day, respectively. In the current study towns, water provision mechanism of peri-urban cattle fatteners was labor intensive.

Since, cattle fattening activities needs ample amount of water for manure management, farm equipment, watering and cattle cleaning. The entire cattle fatteners in both study towns have no information about the amount of water provided per cattle per fattening duration. This is due to lack of awareness and better consideration. According to Adugna (2008) restriction of water intake lowers feed intake, nitrogen retention and loss of nitrogen in the feces. On the other hand, it increases excretion of urea in the urine. Cattle that are gaining weight require more water than those that are losing weight. As per group discussions and filed observations, urban and peri-urban cattle fatteners in both study towns were provide water-using pipeline using water storage equipment and carry water can, respectively. Water provision mechanism of peri-urban cattle fatteners was labor intensive and due to such difficulties, some of peri-urban cattle fatteners in Dessie and Kombolcha towns were provided water two and three day after (Table 1). 
The entire cattle fatteners $(100 \%)$ in both study towns have no information about the amount of water provided per cattle per fattening duration.

\section{Salt supplementation practices}

In the current both study towns all of urban and peri-urban cattle fatteners $(100 \%)$ were provide salt for fattening cattle. Because, they were believed that provision of salt to the fattening cattle would protect cattle from different diseases, increase feed appetite, improve the meat quality, it helps the cattle to drink ample water and to take feed, for ease management and to accustomed fattening cattle easily. The entire peri-urban (100\%) and urban $(100 \%)$ cattle fatteners in both study towns were provided salt in the form of block or locally called 'Ganfur' (Table 2 and Figure 1) and via mix with the ration, respectively. Salt provision frequency of urban cattle fatteners (100 $\%$ ) in both study towns were depends on the frequency of feed provision and the amount of salt provided per cattle was determined using hand. One mature person hand of powdered salt was provided/cattle/day mixed with different feed ingredients, which was estimated 200 gram. On average urban cattle fatteners were provided $9 \mathrm{~kg}$ of salt/cattle/ fattening duration. In contrast, peri-urban cattle fatteners in both study towns were provided block of $1 / 4,2 / 4$ and full block of salt once for unknown fattening days. The overall studied cattle fatteners were obtained salt from market (Table 2).

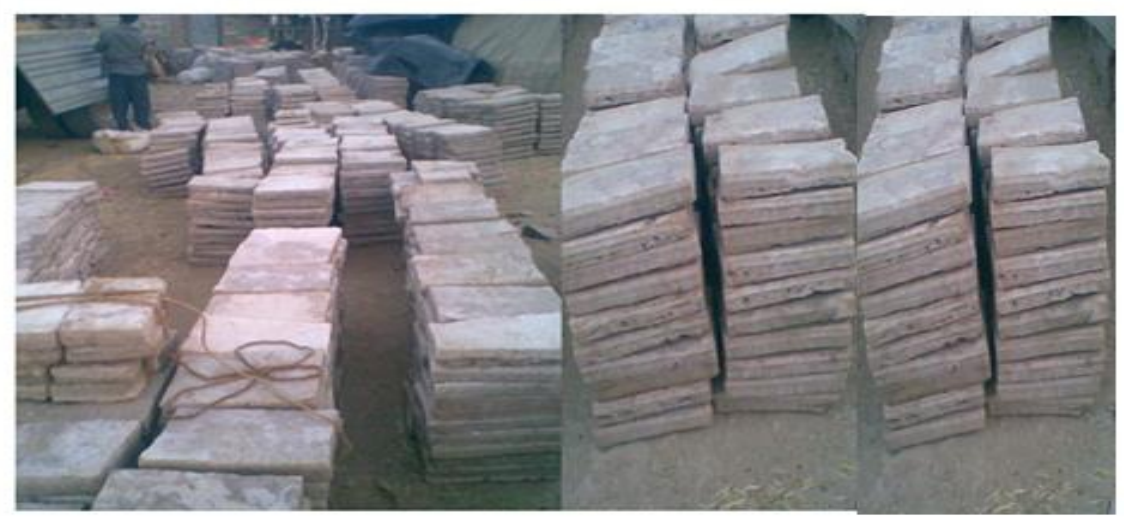

Figure 1. Block of salt

As per group discussion, way of salt supplementation practice has impact on amount and effect use of resources when the offered block of salt finished the peri-urban cattle fatteners were forced to provide additional salt. Such salt provision practice has its merit and shortcomings. It was difficult to determine the amount of salt provided per cattle per fattening duration. Moreover, some of salt portion become out of use due to different dirties and 
breakage. Oppositely, provision of salt in the form of block has advantage for the cattle to take the required amount by themselves. Powder salt provision in the case of urban cattle fatteners may create deficit or extra provision unless otherwise they were properly calculated. Generally, the amount and way of salt offered was varies based on urban and peri-urban cattle fatteners category and from fatteners to fatteners. According to Aaron and Rick (2011) report several factors influence the concentration of salt required in a mix to achieve a desired feed intake. It is usually necessary to increase the salt content of the mix over a period of time as cattle become accustomed to the high salt level.

Table 2. Salt provision practices for fattening cattle in Dessie and Kombolcha towns

\begin{tabular}{|c|c|c|c|c|c|c|c|}
\hline \multirow[t]{2}{*}{ Parameters } & \multicolumn{3}{|c|}{ Dessie town $\mathrm{n}(\%)$} & \multicolumn{3}{|c|}{$\begin{array}{c}\text { Kombolcha town } \\
\mathrm{n}(\%)\end{array}$} & \multirow{2}{*}{$\begin{array}{c}\begin{array}{c}\text { Overall } \\
\text { total } \\
\mathrm{n}=337\end{array} \\
\end{array}$} \\
\hline & $\begin{array}{c}\text { PUK } \\
\mathrm{n}=149\end{array}$ & $\begin{array}{c}\text { UK } \\
\mathrm{n}=41\end{array}$ & $\begin{array}{c}\text { Total } \\
\mathrm{n}=190\end{array}$ & $\begin{array}{c}\text { PUK } \\
\mathrm{n}=81\end{array}$ & $\begin{array}{c}\mathrm{UK} \\
\mathrm{n}=66\end{array}$ & $\begin{array}{c}\text { Total } \\
\mathrm{n}=147\end{array}$ & \\
\hline \multicolumn{8}{|l|}{ Salt provision practices } \\
\hline - Yes & $149(100)$ & $\begin{array}{c}41 \\
(100)\end{array}$ & $\begin{array}{c}190 \\
(100)\end{array}$ & $\begin{array}{c}81 \\
(100)\end{array}$ & $\begin{array}{c}66 \\
(100)\end{array}$ & $\begin{array}{c}147 \\
(100)\end{array}$ & $\begin{array}{c}337 \\
(100)\end{array}$ \\
\hline - $\quad$ No & $0(0.0)$ & $0(0.0)$ & $0(0.0)$ & $0(0.0)$ & $0(0.0)$ & $0(0.0)$ & $0(0.0)$ \\
\hline \multicolumn{8}{|l|}{$\begin{array}{l}\text { Mechanism of salt } \\
\text { provision }\end{array}$} \\
\hline - Mixing with ration & $0(0.0)$ & $\begin{array}{c}41 \\
(100)\end{array}$ & $\begin{array}{c}41 \\
(21.6)\end{array}$ & $0(0.0)$ & $\begin{array}{c}66 \\
(100)\end{array}$ & $\begin{array}{c}66 \\
(44.9)\end{array}$ & $\begin{array}{c}107 \\
(33.2)\end{array}$ \\
\hline - Block 'ganfur' & $149(100)$ & $0(0.0)$ & $\begin{array}{c}149 \\
(78.4)\end{array}$ & $\begin{array}{c}81 \\
(100)\end{array}$ & $0(0.0)$ & $\begin{array}{c}81 \\
(55.1)\end{array}$ & $\begin{array}{c}230 \\
(66.8)\end{array}$ \\
\hline \multicolumn{8}{|l|}{$\begin{array}{l}\text { Frequency of salt } \\
\text { provision }\end{array}$} \\
\hline $\begin{array}{l}\text { It depends the } \\
\text { concentrate feed } \\
\text { provision }\end{array}$ & $0(0.0)$ & $\begin{array}{c}41 \\
(100)\end{array}$ & $\begin{array}{c}41 \\
(21.6)\end{array}$ & $0(0.0)$ & $\begin{array}{c}66 \\
(100)\end{array}$ & $\begin{array}{c}66 \\
(44.9)\end{array}$ & $\begin{array}{c}107 \\
(33.2)\end{array}$ \\
\hline - Once as a whole & $149(100)$ & $0(0.0)$ & $\begin{array}{c}149 \\
(78.4)\end{array}$ & $\begin{array}{c}81 \\
(100)\end{array}$ & $0(0.0)$ & $\begin{array}{c}81 \\
(55.1)\end{array}$ & $\begin{array}{c}230 \\
(66.8)\end{array}$ \\
\hline \multicolumn{8}{|l|}{$\begin{array}{l}\text { Amount of salt } \\
\text { provided }\end{array}$} \\
\hline $\begin{array}{l}\text { One hand full } \\
\text { powdered }\end{array}$ & $0(0.0)$ & $\begin{array}{c}41 \\
(100)\end{array}$ & $\begin{array}{c}41 \\
(21.6)\end{array}$ & $0(0.0)$ & $\begin{array}{c}66 \\
(100)\end{array}$ & $\begin{array}{c}66 \\
(44.9)\end{array}$ & $\begin{array}{c}107 \\
(33.2)\end{array}$ \\
\hline - $\quad 1 / 4$ ganfur & $13(8.7)$ & $0(0.0)$ & $13(6.8)$ & $0(0.0)$ & $0(0.0)$ & $0(0.0)$ & $13(3.4)$ \\
\hline - $2 / 4$ ganfur & $\begin{array}{c}330 \\
(22.1)\end{array}$ & $0(0.0)$ & $\begin{array}{c}33 \\
(17.4)\end{array}$ & $0(0.0)$ & $0(0.0)$ & $0(0.0)$ & $33(8.7)$ \\
\hline - One ganfur & $\begin{array}{c}103 \\
(69.1)\end{array}$ & $0(0.0)$ & $\begin{array}{c}103 \\
(54.2)\end{array}$ & $81(100)$ & $0(0.0)$ & $\begin{array}{c}81(55.1 \\
)\end{array}$ & $\begin{array}{c}184 \\
(54.5)\end{array}$ \\
\hline
\end{tabular}

PUK refers to Peri-urban Kebeles; UK denotes to Urban Kebeles

\section{Conclusion}

The entire cattle fatteners in both towns were provide pure water for fattening cattle, which comes from pipe and hand wells. They were also 
provided salt for fattening cattle. However, salt provision practices not weight base. It is black recommendation. Therefore, fattener's salt provision practices should be supported with scientific knowledge.

\section{Acknowledgements}

The authors would like to acknowledge College of Veterinary Medicine and Agriculture of Addis Ababa University and Arba Minch University, Ethiopia for funding the study. We also acknowledge the urban and peri-urban cattle fatteners, Agricultural Experts, Development Agents in Dessie and Kombolcha towns for their willingness to provide the necessary information.

\section{References:}

1. Aaron L. Berger and Rick J. Rasby (2011). Limiting Feed Intake with Salt in Beef Cattle Diets. University of Nebraska-Lincoln Extension, Institute of Agriculture and Natural Resources.

2. Adugna Tolera (2008). Feed Resources and Feeding Management: A Manual For Feedlot Operators and Development Workers. Ethiopian Sanitary and Phytosanitary Standards and Livestock and Meat Marketing Program (SPS-LMM), Addis Ababa, pp 43.

3. Arsham ,H. (2007). Perturbed Matrix Inversion with Application to Linear Programs Simplex Method. Applied Mathematics and Computation, 188: 801-807.

4. Dawit ,B. (2013). Economic and Social Vulnerability Of Rural Urban Migrant Women in Dessie Town, South Wollo Zone, Amhara Regional State, M.A Thesis.

5. Eskinder, Z, Y.Eyassu and H. Mitiku (2010). Assessment of the impact of industrial effluents on the quality of irrigation water and changes on soil characteristics (a case of Kombolcha town), fourteenth international water technology conference, 14, 2010, Cairo, Egypt.

6. Fikru S. (2015). Assessment of Cattle Fattening and Marketing Practice in Harshin District of Somali Regional State, Ethiopia. J Adv Dairy Res. 3: 137. doi:10.4172/2329-888X.1000137

7. Lawton Stewart (2013). Mineral Supplements for Beef Cattle, University of Georgia

8. Muluwork, Z. (2014). An assessment of livelihood and food security of farmers displaced due to urban expansion, the case of Kombolcha town in Amhara national regional state, Ethiopia, a thesis report.

9. Shitahun Mulu (2009). Feed Resources Availability, Cattle Fattening Practices and Marketing System in Bure Woreda, Amhara Region. MSc. Thesis Presented to the School of Graduate Studies of Mekelle 
University. Faculty of Dry Land Agriculture and Natural Resources Department of Animal, Range and Wildlife Sciences.

10. Tsegay Lijalem, Amanuel Daniel and Tegsse Ermias (2016). Assessment of Beef Cattle Fattening in Selected Districts of Hadya Zone, Southern Ethiopia, Journal of Biology, Agriculture and Healthcare, Vol.6, No.5, 2016. 